\title{
Correlation between Adversity Quotient (AQ) with IQ, EQ and SQ Among Polytechnic Students Using Rasch Model
}

\author{
Mohd Effendi @ Ewan Mohd Matore ${ }^{1 *}$ and Ahmad Zamri Khairani ${ }^{2}$ \\ 'Faculty of Education, Universiti Kebangsaan Malaysia43600 UKM, Bangi, Selangor, Malaysia; \\ effendi_ewan@yahoo.com \\ 25chool of Educational Studies, Universiti Sains Malaysia, 11800 Penang, Malaysia; ahmadzamri@usm.my
}

\begin{abstract}
Objective: This research aims to study the relationship between Adversity Quotient (AQ) with dominant intelligence quotients such as IQ, EQ, and SQ in the National Education Philosophy (NEP) among students in polytechnics. Methods/ Analysis: The research used survey with four sets of questionnaires to measure all types of intelligences. A total of 1,845 respondents involving five polytechnics were selected according to zone by using the proportionate clustered multistage stratified sampling technique. Findings: The study shows a moderate positive correlation of AQ relationship with EQ $(\mathrm{r}=$ $0.519, p=.000, \mathrm{~N}=1845)$ and $\mathrm{AQ}$ with $\mathrm{SQ}(\mathrm{r}=0.485, p=.000, \mathrm{~N}=1845)$. In addition, there is a very weak positive correlation $(\mathrm{r}=0.019, p=.408, \mathrm{n}=1845)$ between AQ with IQ of polytechnic students in Malaysia. The follow ups are necessary to strengthen AQ with EQ and SQ through suitable program of self-development. Application/Improvement: This paper makes a significant contribution to correlating intelligences with the interval data using Rasch model. It also shows the effort to explore the potential of $\mathrm{AQ}$ in empowering students with other types of intelligences for polytechnic students in Malaysia. It gives a great recommendation where AQ can be a strong predictor to enhance EQ and SQ in increasing students' performance.
\end{abstract}

Keywords: AQ EQ, IQ, Rasch Model, SQ

\section{Introduction}

Education is a balanced process to develop an individual's potential from the aspects of physical, emotional, spiritual, intellectual and social. Education allows human to completely develop personality, emotional, spiritual and physical potentials $\stackrel{1}{ }$. Basically, education nowadays is the best protection to face competition among graduates. It is becoming very competitive to fight for employment. Rapid technological advances and challenges of current issues require vocational and technical education to train manpower to become more competent, innovative, resilient, competitive and able to adapt themselves with different situations in industries and employments. Technical and Vocational Education (TVE) is directly responsible for the development of quality manpower that can compete globally. Currently available TVE curriculum is more focused only on producing highly skilled manpower ${ }^{2}$. It is now time for the country to implement another important quotient in NEP, which is AQ. It enables students to become more resilient towards the challenges. A significant similarity proves the needs to relate AQ with IQ (mental and cognitive), AQ with EQ (emotion and feelings) and AQ with SQ (spiritual) in line with a previous study who suggested that the relationship of AQ with IQ, EQ and SQ should be further studied ${ }^{3}$. Adversity is often associated with the misery or problem faced by someone. There are two types of adversity. One of them is the inner adversity, which includes lack of confidence, fear, anxiety, depression, loneliness, health problems, insom-

*Author for correspondence 
nia, uncertainties and others. Another type of adversity is the outer adversity, which involves external factors such as economic problems, failure in examination; computer broke down, scratched cars, natural disasters and others. However, this type of adversity gives a negative impact or is expected to give a negative impact towards something that needs to be given attention to ${ }^{4,5}$. Adversity dilemma emerges as the challenges are getting worse, hence, more people could not face and overcome the challenges. This issue is very worrying as it is related with the attitude of giving up and despair for an individual in facing much worse challenges ${ }^{6}$.

In the context of vocational and technical education especially the polytechnic, one of the main education agendas of Malaysia is Polytechnic Transformation Agenda that was launched on $25^{\text {th }}$ February 2010. It is designed for the implementation throughout 2009 until 2020, which is intended to contribute in increasing the number of highly skilled manpower. This transformation is a huge challenge for students due to changes in educational system will surely require those involved in the vocational and educational education process to work together in ensuring the success of this transformation ${ }^{7}$. More particularly, the adversity among students also consists of both inner and outer aspects ${ }^{4}$. For example, a previous study on students' adversity in seven polytechnics had identified various adversities, such as inner adversity (fear of failure in examination, anxious for examination, low self-esteem and fear of unemployment), as well as outer adversity (textbooks are hard to understand, in need of money to further study and uncomfortable living environment) ${ }^{8}$. Hence, students' misery on these challenges should be addressed by understanding AQ.

\section{Adversity Quotient (AQ)}

Terminologically, AQ means the ability or capability of an individual to put up a struggle in facing and overcoming adversities, problems or difficulties and also changed them into an opportunity for greater achievement ${ }^{6}$. $\mathrm{AQ}$ is a new paradigm that is very useful when there is adversity that appears in all walks of life ${ }^{9}$. AQ variable is also relatively new among the majority of individuals ${ }^{10}$. One's ability to face adversities in their life and change the adversities into an opportunity to create success is known as $\mathrm{AQ}^{6}$. The idea of $\mathrm{AQ}$ is produced as there has a question on why two individuals with similar IQ and
EQ, but handle life's adversities differently. Operationally, $\mathrm{AQ}$ is measured using four constructs, which are Control, Ownership, Reach and Endurance. AQ is able to predict success. The definition of AQ can be categorized into three, which are: (i) the conceptual framework to increase all facets of success; (ii) the measure of how one responds to adversity; and (iii) a network of scientific tools based on knowledge to improve one's response towards adversity ${ }^{6}$. In the educational perspective, AQ is the ability that is needed to keep fighting when students face difficulty in achieving their performance. Basically, AQ can predict resilience and persistence of a person and can be used to enhance the effectiveness of teams, relationships, families, communities, cultures, societies and organizations 9 .

\section{Integration of Philosophy with $\mathrm{AQ}$}

In reality, most individuals suffer from misery that can be categorized into four parts, which are physical, emotional, mental and spiritualı. This concept of adversity and misery is in parallel with NEP, which is the aspect of Physical Quotient (PQ), Emotional Quotient (EQ), Spiritual Quotient (SQ) and Intellectual Quotient (IQ). The parallelism can explain how the adoption of AQ concept in the stream of NEP and TVE has the potential to overcome and recover from misery and adversity based on the adversity concept $t^{4}$. So far, AQ is placed separately with quotient in NEP and TVE. In an effort to integrate AQ with both streams of philosophy, hence the relationship between AQ with the main quotient of the both streams of philosophy of NEP and TVE should be studied. The integration of NEP with TVE is very important to develop balanced and harmonic manpower in the aspects of physical, emotional, spiritual and intellectual ${ }^{1}$. The adversity concept with four categories, which are mental, emotional, physical and spiritual adversities $^{4}$, is in tandem with the enhancement of NEP, which is the aspects of PQ, EQ, SQ and IQ, or even for TVE, which are PQ, EQ, SQ, IQ and RQ. However, three types of quotients that are always been given attention to are EQ, SQ and IQ. The selection that focuses on three types of quotients is relevant as IQ, EQ, and SQ are quotients' trio that cannot be separated from one's life until they can be developed comprehensively and become balanced. Previous study also shows that IQ, EQ and SQ have a significant influence on graduates' ethical attitude ${ }^{\underline{11}}$. IQ, 
EQ and SQ are also of individual's potential that cannot be separated as the spiritual system cannot stand on its own. The role and growth of IQ, EQ and SQ in the education world particularly have a very important meaning to develop individuals with good dignity either physically or psychologically in order to create a strong improvement of human quality $\underline{12}$.

The integration of AQ with IQ, EQ and SQ has been implemented such as the existence of Quantum Quotient (QQ), which is a human quotient that can maximize the overall self-potential balanced, synergically and comprehensively, which cover IQ, EQ, AQ and SQ ${ }^{13}$. Similarly with the aspect of pedagogy in education, good pedagogy is about identifying and maximizing the cognitive potential of students (IQ), strengthening their management of emotions and interpersonal skills (EQ), developing their task persistence (AQ), and ultimately helping them develop their spiritual life (SQ) so that they fulfill their assignment in God's kingdom ${ }^{14}$. This relationship shall give a huge and significant contribution in terms of the development of NEP towards building a more resilient workforce.

\section{Relationship of $A Q, I Q, E Q$ and SQ}

Previous study has proven that AQ is related with other aspects of quotient such as IQ, EQ and SQ. This effort is supported by the existence of interrelationship between quotients ${ }^{15}$. This relationship is important to prove the importance of $\mathrm{AQ}$, which is equal with other aspects of quotient that must be given attention to strengthen the educational philosophy stream. Unfortunately, there is a lack of previous studies that focused on the relationship between AQ with other quotients. The study found a relationship between AQ and MQ based on year and types of program for students in Thailand $\frac{16}{}$. According to the previous study, there was a positive relationship among $A Q$, EQ, MQ and students' academic achievement in Pattani, Thailand ${ }^{17}$. The relationship between AQ and EQ with the personality of Chinese businessmen in Thailand and China. The results showed that AQ had a positive relationship with EQ for both groups ${ }^{\frac{18}{18}}$. In Indonesia, a previous study showed a positive relationship on the learning based on SEIA - Q (consists of SQ, EQ, IQ and AQ) with multiple intelligences including verbal-linguistic, mathematical logic, kinesthetic, interpersonal, intrapersonal, visual space, naturalist and music ${ }^{19}$. Hence, there is a need to study the existence of the relationship among quotients to strengthen the position of AQ in the NEP and TVE streams particularly in the Malaysian context. As there is a huge potential for AQ to be correlated with other quotients, as well academic achievements as shown in previous studies through educational context, therefore, there is an urgent need to study the relationship between AQ with IQ, EQ, SQ and academic achievements in the context of polytechnic education in Malaysia, which is rarely discussed.

\section{Rasch Model}

Item Response Theory model (IRT) is tested in advance to find out their suitability or accuracy between the model and the data to be used. The IRT is based on a number of parameters $(1,2$, and 3$)$ to describe the Function Response Item (FRI) ${ }^{20}$. Selection of the most appropriate model depends on the type of test questions and their score. One of the IRT model used in most psychological tests is the Rasch model or better known as One Parameter Logistic Model A (1-PLM). Rasch measurement model refers to one idea, principle, guideline, or technique that allows a measurement to be made on a latent nature. The intended measurement does not only refer to the percentage or the highest number of scores, but this model allows the creation of a scale measurement similar to the scientific scale measurement, which in turn allows the measurement of weight or height to be made. The Rasch model has been widely used in various fields, especially in the evaluation of education and the psychology of education, to measure the level of performance and cognitive assessment ${ }^{21}$.

This model arranges individuals based on abilities and items are sorted based on difficulty ${ }^{22}$. This model also helps to form a scale based on the set of items being studied and focuses on the item and individuals as compared to the test scores ${ }^{23}$. Measurement process based Rasch model can overcome shortcomings, flaws, and defects in the use of raw scores as the ability and the item for the CTT framework analysis ${ }^{24}$. The Rasch model assumes that in every item there exists only a parameter of difficulty. It is also assumes that all items have the same discrimination index and is confident that students with low capabilities will not guess in order to get the correct answer for items that they do not know ${ }^{20}$. The Rasch model in this study only serves to transform the ordinal data to an interval type of data to suit parametric test that will be used. 
Based on the assumptions and measurement capabilities of Classical Test Theory (CTT) on a rating scale, several limitations have been identified. One of it is a data rating scale such as Likert scale, which is an ordinal type of data. This scale is ranking and when ranking increases, so does the trait. However, we cannot assume that increase in rank shows a similar increase between one scale and the other scales. For example, for a five-point Likert scale in which the difference between the scales of agree and strongly agree is probably not the same as the difference between disagree and strongly disagree or disagree with neutral. Response from a survey based on theory is still a theory in nature or a continuum. Thus, "the difference in raw score between pairs of points does not necessarily imply the same number of constructs being studied" 25. Only the interval and ratio type of data can be used for the actual measurement or for parametric tests (that is, regression, Analysis Of Variance (ANOVA), and others). Nonetheless, a rating scale such as the Likert scale for CTT analysis is often mistaken as an interval data and misused in parametric statistical procedures ${ }^{26}$.

The uneven build-up of measurement (intangible) can be overcome with Rasch model. If data from these ordinal type of response is placed in the scatter plot, it will create a sigmoid curve (S curve), where the curve does not have irregular intervals which is a precondition of a measurement. Without irregular intervals, it would be impossible for us to predict a possibility. To overcome this problem, a linear regression is used to produce a straight line that gives the best fit to all points of response towards plot like equation (1). Further forecasts are done by determining the crossover point of interpolation or extrapolation 21 .

$$
y=m x+c
$$

However, to get the best fit line which is the difference between the actual point $(y)$ and the forecast point $\left(y_{\mathrm{i}}\right)$, there is an error (e) as in equation (2). By accepting the fact that there will always be errors in the forecast model, then the reliability on the deterministic model will be significantly reduced.

$$
y+y_{i}=e
$$

This can be resolved by turning it into a model of probability of forecast error $y$ by incorporating forecast error in the formula of equation (3). $y=m x+c+e$

Based on the philosophy of Rasch model, the data obtained must adhere to the principle or in other words the data must fit the model. From Rasch perspective, there is no need to explain the data. What is needed is to test whether the data allow measurement on a linear interval scale, especially in cumulative response process. In short, the probability of success depends on the difference between the ability of an individual to the level of difficulty of an item. Rasch model combines algorithms that specify the expected probability of an item as $i$ and individual capacity as $n$ in the form of mathematical equa$\operatorname{tion}^{22}$. The mathematical formula for the model refers to equation (4).

$$
\begin{aligned}
& \mathrm{P}_{n i}\left(x_{n i}=\frac{1}{B_{n}}, D_{i}\right)=\frac{e^{\left(B_{n}-D_{i}\right)}}{1+e^{\left(B_{n}-D_{i}\right)}} \\
& \qquad \mathrm{P}_{n i}\left(x_{n i}=\frac{1}{B_{n}}, D_{i}\right)
\end{aligned}
$$

is the probability of individual $\mathrm{n}$ on item $\mathrm{i}$ giving correct response $(\mathrm{x}=1)$; on individual capacity, $B_{n}$ and level of difficulty of item, $D_{i}$. The value of $e$ is Euler's constant logarithmic number of 2.7183. This equation can be simplified by introducing the arithmetic sign of this possibility and summarises the entire formula as in equation (5).

$$
\ln [\mathrm{P}(\theta)]=\ln \left[\frac{e^{\left(B_{n}-D_{i}\right)}}{1+e^{\left(B_{n}-D_{i}\right)}}\right]
$$

The value of $x=1$ will be reduced and will be called logits equation. Therefore, the probability likelihood of a success or In $[\mathrm{P}(\theta)]=\mathrm{B}_{n}-\mathrm{D}_{i}$ which means (the ability of an individual - the difficulty of an item) as in equation (6).

$$
\ln [\mathrm{P}(\theta)]=B_{n}-D_{i}
$$

In the context of the study, the relationship is examined using correlation analysis, which is a measure of strength of the linear relationship between two variables ( $x$ and $y$ ) being studied, such as AQ and IQ, AQ and EQ, $A Q$ and $S Q$. In order to determine the strength of the linear relationship between these two variables with more accurate findings, quantitative measurement through correlation coefficient of the product moment by Pearson will be used. Based on the measures of association, one of 
the conditions for the use of inferential statistical analysis is that both variables must have the measurement type of interval or ratio data. However, this condition is not adhered to because the Likert scale measurement of AQ, $\mathrm{EQ}$, and SQ are ordinal type of data. Thus, there is a need to transform the ordinal data into interval data through the logits by Rasch model other than to obtain a linear interval scale.

\section{Methodology}

\subsection{Demographic Profile}

The study was successfully implemented with a rate of return exceeding 95\%. A total of 1845 instruments were collected and entirely filled up by students out of 1892 instruments that were distributed. This rate of return is acceptable because it is more than $75 \%$. The profile shows 456 (24.7\%) samples dominated by the polytechnic from West Zone as compared to Borneo Zone of 258 (14.0\%). The number of samples is relatively balanced based on gender in which there are 994 male students (53.9\%) and 851 females (46.1\%). On the aspect of academic year, the first-year students dominated the sample around 619 (33.6\%). The Department of General Studies (JKA) involves with 490 (26.6\%) and Department of Commerce with 442 (24.0\%) samples. Most of the respondents are between 18 to 23 years old.

\subsection{Sampling}

Sampling technique used is the proportionate clustered multistage stratified sampling technique. The population of the study was 18,828 . Clusters here means the sampling location of study, conducted according to five zones and that of the north, west, east, south, and Borneo. This study used the proportion of ten percent's of the total population of each department as proposed ${ }^{28,29}$. It involves all polytechnic students from semesters two, three, five, and six. Three strata are used and those are the program of study (first stratum), year of study (second stratum), and gender (third stratum). A total of five polytechnics according to five zones involved, namely West, North, East, South and Borneo zone.

\subsection{Instrumentations}

Four instruments are used in this study, namely the IKBAR instrument to test AQ with four constructs of (i) control;(ii) ownership;(iii) reach and (iv) endurance; EQ was measured by USMEQ-i with seven constructs of (i) emotional control; (ii) emotional maturity; (iii) emotional conscientiousness; (iv) emotional awareness; (v) emotional commitment; (vi) emotional fortitude and (ix) emotional expression ${ }^{30}$, SQ was measured by Integrated Spiritual Intelligence Scale (ISIS) with five constructs of (i) consciousness; (ii) grace; (iii) meaning; (iv) transcendence and (v) truth $\underline{1}$, and the IQ was measured by Ravens Advanced Progressive Matrices (RAPM) which just contained general intelligence ${ }^{32}$. The consideration of this research just covered the overall score and not calculating score of the each constructs. The instruments for has undergone a pilot study to test the validity and its reliability such as IKBAR for AQ ${ }^{33,34}$ USMEQ-i for EQ ${ }^{35}$, RAPM for IQ and ISIS for SQ. IKBAR also evaluated by using nine professional experts and 28 lay experts for the purpose of content validity ${ }^{33}$.This study sets the measurement of $A Q, E Q$, and SQ in the Likert scale while IQ is using the score marks. The ordinal data in the Likert scale is converted to the logits value to make it an interval value. Consideration for skewness and kurtosis selection is done to test the normality on the justification of a large sample size of more than $200^{36}$. The results show that the data are scattered normally just like previous research setting through the skewness value $e^{36-38}$ and kurtosis $\frac{37,38}{}$. Therefore, in consideration of the type of data, sample size, and normality, parametric analysis chosen is the Pearson product moment correlation.

\section{Discussions}

The first finding shows a moderate positive correlation $(\mathrm{r}=$ $0.519, p=.000, \mathrm{~N}=1845$ ) between AQ and EQ intelligence of polytechnic students in Malaysia. This means that AQ scores are related to the respondents' EQ score. Relation to construct AQ and those are of control, ownership, reach, and endurance with EQ are also refined. The findings show a moderate correlation between the strength of EQ and control $(\mathrm{r}=0.436, p=.000)$, EQ and ownership $(\mathrm{r}=0.409, p=.000)$, EQ and reach $(\mathrm{r}=0.489, p=$ $.000)$, and EQ with endurance $(r=0.439, p=.000)$. The second finding shows a moderate positive correlation $(\mathrm{r}$ $=0.485, p=.000, \mathrm{n}=1845$ ) between AQ and SQ intelligence of polytechnic students in Malaysia. This finding implies that AQ scores are related to the respondents' SQ score. The results show a moderate correlation between SQ and control $(\mathrm{r}=0.397, p=.000)$, SQ and owner- 
ship $(\mathrm{r}=0.404, p=.000)$, SQ and reach $(\mathrm{r}=0438, p=$ $.000)$, and SQ with endurance $(\mathrm{r}=0.412, p=.000)$. The third finding shows a very weak positive correlation $(\mathrm{r}=$ $0.019, p=.408, \mathrm{n}=1845$ ) between AQ and IQ of polytechnic students in Malaysia. This finding means that the AQ score is not related to the respondents' IQ scores. The results show a very weak correlation strength between IQ and control ( $\mathrm{r}=0.045, p=.055)$, IQ and ownership ( $\mathrm{r}=$ $0.004, p=.852)$, IQ and reach $(\mathrm{r}=0.038, p=.101)$, and IQ with endurance $(\mathrm{r}=0.011, p=.641)$. In conclusion, the study indicated the existence of a statistically significant relationship between AQ with EQ and SQ, but having no correlation with IQ. The previous study also shows that AQ had contributed only $0.9 \%(r=.098)$ changes in the variance of academic achievement score ${ }^{\frac{39}{9}}$. It means that AQ has not fully related or supported to the cognitive aspect of polytechnic students.

The findings obtained strengthen the recommendations of past studies linking AQ with other

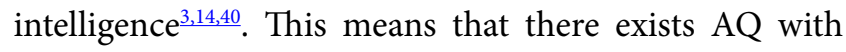
other intelligence such as EQ and SQ. The findings on the relationship between AQ and EQ supports past studies, such as the existence of a positive relationship between $\mathrm{AQ}$ with $\mathrm{EQ}^{17,18,41}$. Based on the original concept of $\mathrm{AQ}$, the relationship of AQ with IQ and EQ has been discussed where IQ and EQ are not the only determinants of a person's success but it is the $\mathrm{AQ}^{11}$. Yet, the findings of AQ and IQ do not indicate the existence of correlation in the context of this study and thus contrary to previous studies $\underline{42}$. As for the relationship between AQ and SQ, the findings are supported by previous studies that there is a correlation between AQ and SQ in the conceptual development of human resources ${ }^{43}$. However, the results are different when the previous study showed a negative relationship between $\mathrm{AQ}$ and $\mathrm{SQ}^{44}$. Although the discussion on the basic concepts of communication AQ involves only with IQ and EQ, this study contributes to the potential relevance of AQ with SQ. In fact, the contribution towards the NEP is also evident when AQ has a relationship with two out of three intelligence quotients, namely EQ and SQ.

\section{Conclusions}

This paperwork contributed for two important fields which are for psychometric and intelligences part. One of the criteria for correlation analysis is the type of data must be interval. The Rasch model fully contributed in transforming ordinal data (from CTT) to interval data for the purpose of correlating AQ with other variables of intelligences. For intelligence, it was conceptually suggested that AQ will be able to enhance quotients of IQ, EQ and SQ in producing a first class human capital, as well as ideal personality. The potential shown by AQ presents its ability to be equally important with other quotients. There is not much that has been explored for AQ in the education aspect in Malaysia. In a competitive era, tough challenges in education and career will require high and firm fighting spirit. Students' resilience can be strengthening although they face with various challenges ahead especially for job performance and satisfaction. It is clear that NEP, which was introduced in 1988 with the effort to develop balanced and harmonic person in the aspects of intellectual, spiritual, emotional and physical, needs changes and flourishes on the aspect of highlighting AQ in the national education system. Now, after more than 25 years, it is time for the education system to uncover and develop individual's potential from the aspect of AQ. AQ has a high potential and should be given attention by educators and education policymakers, in developing effective programs in order to reduce the problems faced by the students. Specifically, the strengthening of AQ in IQ, EQ and SQ can realize one of the main national education agendas, which is Polytechnic Transformation Agenda towards year 2020 and develop highly skilled workers by 2015 . The transformation requires high endurance from polytechnic students and certainly the adoption of NEP requires other quotients in the philosophy streams. AQ is the most potential option as the anchor and catalyst towards more outstanding and lasting Polytechnic Transformation Agenda. Most importantly, the effort of developing AQ should be intensified and not just seen only as a type of quotient.

\section{Acknowledgment}

Special appreciation to the Centre for Research and Development of Polytechnics (CRDP), Putrajaya for allowing us to conduct this study. Similarly, the cooperation of respondents and lecturers from all polytechnics involved.

\section{References}

1. Yek LY, Rohana H. Integrasi peranan falsafah pendidikan kebangsaan dalam pendidikan teknik dan vokasional ke 
arah memantapkan persiapan kerjaya. Journal of Technical, Vocational and Engineering Education. 2012 Mar; 5:35-40.

2. Zuhaila S, Safarin NM, Syukri SM. Penerapan nilai minjaroes dan formula " $3 \mathrm{H}$ " dalam kurikulum PTV. Journal of Technical, Vocational \& Engineering Education. 2012; 5(1):41-55.

3. Alka VRS. A study of secondary school students response to adversity in relation to certain psychological and performance factors [Doctoral thesis]. Mumbai, University of Mumbai; 2012.

4. Stoltz PG, Weihenmayer E. The adversity advantage: turning everyday struggles into everyday greatness. $2^{\text {nd }}$ edition. Fireside: New York; 2010.

5. Stoltz PG. Adversity quotient: mengubah hambatan menjadi peluang. $7^{\text {th }}$ edition. PT Grasindo, Jakarta; 2007.

6. Stoltz PG. Adversity quotient: turning obstacles into opportunities. John Wiley \& Sons: Canada; 1997.

7. Nadya ABN, Rohana H, Amirmudin U. Cabaran-cabaran dalam pendidikan teknik dan vokasional dalam membangunkan sumber manusia. Journal of Edupress. 2011Sep; 1:159-64.

8. Effendi MMM, Zamri KA. Cabaran permasalahan pelajar politeknik menggunakan model Rasch. Proceedings of 2nd International Seminar on Quality and Affordable Education, Skudai: Universiti Teknologi Malaysia; 2013. p. 337-47.

9. Phoolka S, Kaur N. Adversity quotient: a new paradigm to explore. International Journal of Contemporary Business Studies. 2012; 3(4):67-78.

10. Macasaet CJA. Adversity quotient and achievement motivation of selected third year and fourth year psychology students of De La Salle Lipa A.Y. 2012 - 2013 [Bachelor thesis]. Batangas, Philiphines, De La Salle Lipa; 2013.

11. Ridwan T, Iwan T, Unti L. Pengaruh kecerdasan intelektual, kecerdasan emosional dan kecerdasan spiritual terhadap sikap etis mahasiswa akuntansi (Studi pada Perguruan Tinggi Negeri di Kota Makassar Provinsi Sulawesi Selatan). In the Proceedings of Simposium Nasional Akuntansi 9 Padang, Padang; 2006. p. 1-25.

12. Andik RI. Peran intelligence quotient (IQ), emotional quotient (EQ) dan spiritual quotient (SQ) dalam peningkatan mutu pendidikan. Psikoislamika. 2005; 2(2):1-7.

13. Sutama IK. Pendidikan vokasi dan pembangunan global: Politeknik Negeri Bali. Soshum Jurnal Sosial dan Humaniora. 2012; 2(1):63-71.

14. Hetzel J, Stranske T. The IQ, EQ, AQ dan SQ elements of effective pedagogy. Journal of Computer Science. 2007; 10(3):6-9.

15. Azhar AHM. EQ: panduan meningkatkan kecerdasan emosi. PTS Publications Sdn Bhd: Bentong; 2007.

16. Thongsai N. A study of adversity quotient and moral quotient of vocational certificate students in different pro- grams at wanich commercial school, nonthaburi province [Master's thesis]. Bangkok, Thailand, Srinakharinwirot University; 2008.

17. Yodsakun A, Kuha A. Relationship between Emotional Intelligence (EQ), Adversity Quotient (AQ) and Moral Quotient (MQ) towards academic achievement of mattayom suksa two students. Journal of the Faculty of Education. 2008; 19(2):129-42.

18. Kumbanaruk T, Maetheeponkul T. Adversity Quotient (AQ), Emotional Quotient (EQ) and personality of Chinese businesspeople in Thailand and Chinese businesspeople in China. Journal of East Asian Studies. 2008; 13(1):1-18.

19. Lena N. Hubungan antara pembelajaran berbasis SEIA-Q dengan multiple itelligence pada peserta didik (Survei pada mahasiswa program studi manajemen bisnis 2006). Percikan. 2009; 104:37-52.

20. Rahayah AS. Inovasi dalam pengukuran dan penilaian pendidikan. Universiti Kebangsaan Malaysia: Bangi; 2008.

21. Azrilah AA, Saidfudin MM, Azami Z. Asas model pengukuran Rasch: pembentukan skala dan struktur pengukuran. Penerbit UKM: Bangi; 2013.

22. Bond TG, Fox CM. Applying the Rasch model: fundamental measurement in the human sciences. Routledge: New Jersey; 2007.

23. Azrilah AA. Rasch model fundamentals: scale construct and measurement structure. Integrated Advance Planning Sdn Bhd: Kuala Lumpur; 2011.

24. Rahayah AS. Ke arah kesaksamaan penilaian pendidikan: amalan dan cabaran. Universiti Kebangsaan Malaysia: Bangi; 2013.

25. Smith E V, Conrad KM, Chang K, Piazza J. An introduction to Rasch measurement for scale development and person assessment. Journal of Nursing Measurement. 2002 January; 10(3):189-206.

26. Bode RK, Wright BD. Rasch measurement in higher education. In: Smart JC, Tierney WG, editors. Higher Education: Handbook of Theory and Research. Springer Netherlands: Dordrecht. 1999; 14:287-316.

27. Christensen LB, Johnson RB, Turner LA. Research methods, design and analysis. $11^{\text {th }}$ edition. Pearson Education: Boston; 2011.

28. Gay LR, Mills GE, Airasian P. Educational research: competencies for analysis and applications. $10^{\text {th }}$ edition. Merrill Prentice Hall: Upper Saddle River, New Jersey; 2012.

29. Zainuddin A. Research methodology and data analysis. UiTM Press: Shah Alam;

30. Bahri YMS, Fuad ARA, Rahman EA. The USM Emotional Quotient Inventory 2012. (USMEQ-i) manual. Kota Bharu; 2010 Feb.

31. Amram Y, Dryer DC. The Integrated Spiritual Intelligence Scale (ISIS): development and preliminary validation. In the 
Proceedings of 116th Annual Conference of the American Psychological Association. Boston; 2008. p. 1-46.

32. Raven JC, Court JH, Raven J. Manual for ravens progressive matrices and vocabulary scales: section 4 (advanced progressive matrices set 1 \& 2). H.K. Lewis \& Co. Ltd. :London; 1977.

33. Effendi MMM, Zamri KA. Assessing the Content Validity of IKBAR using Content Validity Ratio. Australian Journal Basic of Applied Sciences. 2015; 9(7):255-7.

34. Effendi MMM, Zamri KA. Psychometric assessment on adversity quotient instrument (IKBAR) among polytechnic students using Rasch model. In: Mastorakis NE, Rudas I, Shitikova MV, Shmaliy YS editors. In the Proceedings of the International Conference on Education and Educational Technologies (EET), Barcelona, Spain: Institute for Natural Sciences and Engineering; 2015. p. 52-7.

35. Effendi MMM, Zamri KA. Pengujian ciri psikometrik item USMEQ-i dalam kalangan pelajar politeknik menggunakan Model Rasch. Jurnal Teknologi. 2015; 75(1):251-7.

36. Field A. Discovering statistics using SPSS. SAGE Publications: London; 2009.

37. Kim HY. Statistical notes for clinical researchers: assessing normal distribution (2) using skewness and kurtosis. Restorative Dentistry and Endodontics. 2013 February; 38(1):52-4.

38. Kline RB. Becoming a behavioral science researcher: a guide to producing research that matters. Guilford Press: New York; 2009.
39. Effendi MMM, Zamri KA, Nordin AR. The Influence of AQ on the Academic Achievement among Malaysian Polytechnic Students. International Education Studies. 2015; 8(6):69-74.

40. Ratri W. Analysis of leader intelligence in telecommunication industry in Indonesia. Journal of Modern Accounting and Auditing. 2014; 10(1):125-32.

41. Primatika FR, Laily R. Kewirausahaan dalam kaitannya dengan Adversity Quotien dan Emotional Quotien. Jurnal Psikologi Proyeksi. 2010; 5(1):52-64.

42. Sia T. Hubungan antara IQ, EQ, dan AQ dengan prestasi studi pada siswa SMU. Anima Indonesian Psychological Journal. 2001; 17(1):69-92.

43. Tekad W. Peranan kecerdasan spiritual (spiritual quotient) dan kecerdasan dalam menghadapi rintangan (adversity quotient) untuk meningkatkan etos kerja SDM. In: Proceedings of the Konferensi I Asosiasi Psikologi Industri \& Organisasi (APIO), Surabaya: Asosiasi Psikologi Industri \& Organisasi (APIO); 2009. p. 57-63.

44. Heni M. Hubungan adversity quotient dan kecerdasan ruhaniah dengan kecenderungan Post Power Syndrome pada Anggota TNI AU di Lanud Iswahjudi Madiun [Bachelor thesis]. Jawa Tengah, Indonesia, Universitas Muhammadiyah Surakarta; 2008. 